\begin{tabular}{|c|c|}
\hline & Asian Social Work Journal (ASWJ) \\
\hline $\begin{array}{c}\text { ASIAN SOCIAL WORK } \\
\text { JOURAL } \\
\text { (ASW) }\end{array}$ & Volume 3, Issue 2, April 2018 \\
& e-ISSN : 0128-1577 \\
& Journal home page: \\
& www.msocialwork.com \\
\hline
\end{tabular}

\title{
Perceptions of Intra-Familial Child Sexual Abuse and Intimate Parent-Child Interactions
}

\author{
Qian-Wen Xie ${ }^{1}$, Joshua Miller ${ }^{2}$ \\ 1Department of Social Work and Social Administration, The University of Hong Kong, Pokfulam, Hong Kong \\ ${ }^{2}$ Smith College School for Social Work, Northampton, MA, United States \\ Corrrespondence: Joshua Miller (jlmille@smith.edu)
}

\begin{abstract}
The current study aimed to explore Chinese undergraduate students' perceptions of intimate parentchild interactions (IPCI) and intra-familial Child Sexual Abuse (CSA) as well. 354 undergraduate students from 15 universities or colleges in Beijing were recruited to participate in an online-based survey. Results indicated that IPCI such as co-bathing and co-sleeping were very common among Chinese undergraduate students during childhood. Factors including the child's age and gender, as well as the parent's gender involved in IPCI were found to impact respondents' perceptions of the appropriateness of those interactions. Moreover, respondents' perceptions of the appropriateness of parent-child intimate interactions might also be influenced by their childhood experiences of parental interactions and their perceptions of intra-familial CSA. The study suggested that distinguishing intrafamilial CSA from normative IPCI will continue to be contested and culturally shaped. Comprehensive information and public education about intra-familial CSA are needed for the prevention of CSA in Chinese society.
\end{abstract}

Key words: child sexual abuse, parent-child interactions, intra-familial abuse, perceptions, China

\section{Introduction}

Child sexual abuse (CSA) is a social issue of great international concern (Collin-Vezina, Daigneault, \& Hebert, 2013), and it has received growing attention in Mainland China during the past few years (Xie, Qiao, \& Wang, 2016). According to a meta-analysis of 27 studies, $15.3 \%$ of Chinese females and $13.8 \%$ of males reported CSA experiences in childhood (Ji, Finkelhor, \& Dunne, 2013). From 2012 to 2014, there were 7,145 CSA cases heard by courts throughout the country in mainland China, and the number has continued to increase every year (Liu, 2016). Since CSA is still a taboo (Ho \& Kwok, 1991; Li, 2011), and underreporting is a serious problem (Xie, Sun, Chen, Qiao, \& Chan, 2017), the problem of CSA in Chinese society may be more serious than we have realized.

The child protective system (CPS) is in the process of being developed in Mainland China and lags behind other countries (Qiao \& Xie, 2017; Xie et al, 2017). Although CSA is prohibited by laws (e.g., the Criminal Law of the People's Republic of China, the Law of the People's Republic of China on the Protection of Minors, and the Anti-Domestic Violence Law of the People's Republic of China), the procedures of reporting and investigating CSA cases, and protecting abused children are very unclear and there is no system of mandated reporting. 


\section{The Problem of Intra-Familial CSA}

Intra-familial CSA is a very sensitive topic in any society because it takes place within the family. Because of the complex relationships between penetrators and child victims, intra-familial CSA has been considered more severe and harmful than extra-familial CSA (Bornstein, Kaplan, \& Perry, 2007). Prevention of and intervention for intra-familial CSA is especially challenging because of its secrecy, and children often not knowing who to talk to, often feeling ambivalent about sharing family secrets (National Sexual Violence Resource Center [NSVRC], 2012). And when intervention does not go well, it may threaten the child's development, parent-child relationship, and indeed the stability of the whole family system (Magalhães, Taveira, Jardim, Santos, Matos, \& Santos, 2009).

Every society has some forms of intra-familial CSA, although cultural norms and social practices vary considerably. For example, in a US City between 1997 and 2007, 40\% of medical-legal reports of suspected CSA cases $(\mathrm{N}=1,054)$ were intra-familial CSA (Magalhães et al. 2009). According to the U.S. Department of Health and Human Services (U.S. DHHS, 2005), in the US fathers are the most likely perpetrators in substantiated cases of intra-familial CSA in the U.S. Chinese scholars have suggested increased attention be given to intra-familial CSA in Chinese society (Xie et al, 2017). From 2013 to 2015, the Chinese mass media reported 968 CSA cases involving more than 1,790 child victims. Among the 340 CSA cases reported in 2015, 73\% of the perpetrators involved were close acquaintances of, rather than strangers to, the victims, such as fathers, brothers, and stepfathers (China Social Assistant Foundation, 2015; Chen \& Jin, 2016). However, because of the value of the primacy of the family in China, this often obscures the problem of intra-familial CSA. Qualitative studies conducted by Xie and her colleagues (Xie et al., 2017) found that Chinese parents preferred to believe that CSA would not happen within the family. When these parents defined CSA, they did not include intra-familial CSA; instead pointing to threats from outside of the family, such as teachers.

\section{Intimate Parent-child Interactions within A Socio-Cultural Context}

Given increased concerns about the problem of intra-familial CSA, scholars have suggested the importance of distinguishing culturally acceptable intimate parent-child interactions (IPCI) from sexually abusive behaviors within the family (Johnson, 1999; Johnson \& Hooper, 2003; Johnson, Huang, \& Simpson, 2009). Overstepping the boundaries of normal or commonly acceptable IPCI in families may result in serious problems, such as problematic sexual behaviors of children and even CSA (Friedrich, 2002; Gil \& Johnson, 1993; Johnson, 2005). Determining normal IPCI within a given cultural context can establish benchmarks for assessing the risk of CSA and provide valuable information or evidence for child welfare professionals to make decisions about child protection (Johnson, 2007; Johnson et al, 2009).

Socio-cultural context is critical in the discussion of normative IPCI because standards of family practices with children and the propriety of interpersonal touching behaviors vary considerably in different cultures (Dibiase, \& Gunnoe, 2004; Okami, 1995; Rothbaum, Morelli, Pott, \& Liu, 2000; Tahhan, 2008). Socio-cultural factors may impact not only IPCI, but also how people perceive certain interactions and socially construct sexually abusive behaviors (Hestick \& Perrino, 2009; Johnson et al, 2009; Reynolds, \& Birkimer, 2002). According to the Social Norm Theory (Berkowitz, 2003), people internalize a perceived social norm and then evaluate their own behaviors in relation to the internalized sense of what is right and wrong. The answer to the question about whether or not certain IPCIs are problematic or abusive may depend on the social expectations, public perceptions, and internalized guideposts of the appropriateness of these behaviors.

\section{Perceptions of IPCT}

Empirical data regarding public perceptions of IPCI that are ambiguously related to CSA are extremely scant (Miller-Perrin \& Perrin, 2006). Harrison-Speake and Willis (1995) examined public perceptions of the appropriateness of various types of IPCI, including lap-sitting, kissing, bathing, and sleeping, in 
a city of U.S. Results showed that the rates of appropriateness declined as the child got older, and the approval of kissing and bathing was lower for fathers than mothers. Atteberry-Bennett (1987) found that $47 \%$ of professionals and parents from Virginia believed that outside intervention was required when a mother "often" kissed her 10-year-old son on the lips, $51 \%$ when a father "often" entered the bathroom while his 5-year-old daughter was bathing, and $80 \%$ when a father "often" slept in the same bed with his 5-year-old daughter. Johnson and Hooper (2003) studied professionals' perceptions regarding the ages up to which certain parent-child interactions were appropriate between parents and children in the U.S. They found that interactions for opposite-sex family members were generally considered less acceptable than for same sex pairs. Professionals believed that parents might need to stop co-bathing with children after 3.3 years, co-sleeping with children after 5.4 years, and kissing children on the lips after 5 years.

Other factors may also impact people's perceptions of suitable or abusive behaviors, such as the age of child, the gender of the child and perpetrator, the type of behavior, victim-perpetrator relationships (Davies \& Rogers, 2009; Giglio, Wolfteich, Gabrenya, \& Sohn, 2011; Rogers, Davies, Anderson, \& Potton, 2011; Rosenfeld, Seigal, \& Bailey, 1987), and prior information and expectations about CSA (Hyson, Whitehead, \& Prudhoe, 1988; Johnson, 2005).

However, the preponderance of research on perceptions regarding IPCI has been conducted among middle class Western populations in developed countries, especially the U.S., where norms of IPCI may be different from other countries. Relevant discussions launched in diverse socio-cultural contexts are very rare.

\section{Objectives of the Current Study}

The current study aimed to explore childhood experiences of IPCI as recalled by Chinese undergraduate students, and to invite them reflect upon and to assess their perceptions as appropriate IPCI in contrast to intra-familial CSA.

\section{Method}

\section{Participants}

The participants were 354 undergraduate students from 15 universities or colleges in Beijing, China (Table 1). The participants (49\% male; 51\% female) ranged in age from 18 to 28 years $(\mathrm{M}=21.61$, SD $=1.541$ ) and were predominantly ethnically Han Chinse (90\%). Most of them were in the first year $(29 \%)$ or second year $(37 \%)$ of their programs. They came from different provinces and areas of China; the majority were distributed through Northern China (31\%), Eastern China (20\%) and the North-East of China (18\%).

Table 1: Demographic Characteristics $(N=354)$

\begin{tabular}{lll}
\hline Variables & $\mathbf{n}$ & $\mathbf{\%}$ \\
\hline Sex & & \\
$\quad$ Male & 175 & 49.44 \\
$\quad$ Female & 179 & 50.56 \\
Age (years) & & \\
$18-21$ & 180 & 50.8 \\
$22-25$ & 165 & 46.6 \\
$26-29$ & 9 & 2.5 \\
Year at University & & \\
First Year & 101 & 28.53 \\
Second Year & 131 & 37.01 \\
Third Year & 84 & 23.73 \\
\hline
\end{tabular}




\begin{tabular}{lll}
\hline $\begin{array}{l}\text { Fourth or Fifth Year } \\
\text { Ethnicity }\end{array}$ & 38 & 10.73 \\
Han & 320 & 90.40 \\
Others & 34 & 9.60 \\
Place of birth & & \\
Eastern China & 71 & 20.06 \\
Southern China & 9 & 2.54 \\
Central China & 39 & 11.02 \\
Northern China & 108 & 30.51 \\
North-Western China & 30 & 8.47 \\
South-Western China & 32 & 9.04 \\
North-Eastern China & 63 & 17.80 \\
Others & 2 & 0.56 \\
\hline
\end{tabular}

Note: Eastern China includes Shandong, Jiangsu, Anhui, Zhejiang, Fujian, and Shanghai; Southern China includes Guangdong, Guangxi, and Hainan; Central China includes Hubei, Hunan, Henan, and Jiangxi; Northern China includes Beijing, Tianjin, Hebei, Shanxi, and Inner Mongolia; North-Western includes Ningxia, Xinjiang, Qinghai, Shanxi, and Gansu; SouthWestern includes Sichuan, Yunnan, Guizhou, Tibet, and Chongqing; North-Eastern includes Liaoning, Jilin, and Heilongjiang; Others include Hong Kong, Macao, etc.

Most recent undergraduate students were born in the 1990s, and are called the generation of "post-90" in China. Many of them still had to go to public bathrooms and sleep together with parents during childhood because of underdeveloped economic status and limited housing resources in the Mainland in the 1990s. But, the group of "post-90" also grew up in a more open and prosperous environment than previous generations because of economic and market reforms and the development of state- and non-state-owned businesses and corporations in China in the 1990s (Yan, 2010). The generation of "post-90" has gained much attention because this generation was a transition cohort, coming of age at the dawn of China's modernization. Undergraduate students were chosen as participants of the current study because of their special cohort status, availability to access online, and the assumption that it would be also easier for them to recall childhood experiences than older adults.

\section{Instrument}

A self-administered questionnaire was developed based on the research objectives and instruments used in previous studies. We prepared the questionnaire in English initially (in order to obtain US IRB approval) and then translated it into Chinese. The questionnaire was pilot-tested by 20 undergraduate students. We revised some expressions and deleted questions that were confusing. Then, an expert in the field of child welfare in China reviewed the Chinese version of the questionnaire and provided suggestions for minor revisions.

The self-administered questionnaire included four sections. Section I listed seven socio-demographic questions including sex, age, school, grade, ethnicity, birthplace, and monthly expenses. In Section II, questions regarding childhood experiences (under 18 years) of IPCI, such as co-bathing and cosleeping with parents were asked. For example, we asked the question "Did you bathe with your mother before 18 years?" If they answered yes, a follow-up question would be asked, "How old were you the last time when you co-bathed with your mother?" Five options were provided: 0-2 years, 3-6 years, 7-10 years, 11-14 years, and 15-17 years. In section III, a question was asked regarding their agreement with a statement of intra-familial CSA (i.e., "there is a possibility that a child may be sexually abused by his or her parent") was asked. Two options were provided: agree and disagree. In section IV, we partly adopted the instrument used in Harrison-Speake and Willis's (1995) study with minor revisions. Four types of IPCI (i.e., lap-sitting, kissing, co-bathing, and co-sleeping) were assessed and situations involving parent-child interactions were rated on a five-point scale from (1) very inappropriate to (5) very appropriate. For each situation of lap-sitting, kissing, and co-bathing, separate ratings were made based on the age of children $(2,6,10,14$ and 17). The situations were:

i. daughter sits on father's lap

ii. daughter sits on mother's lap 


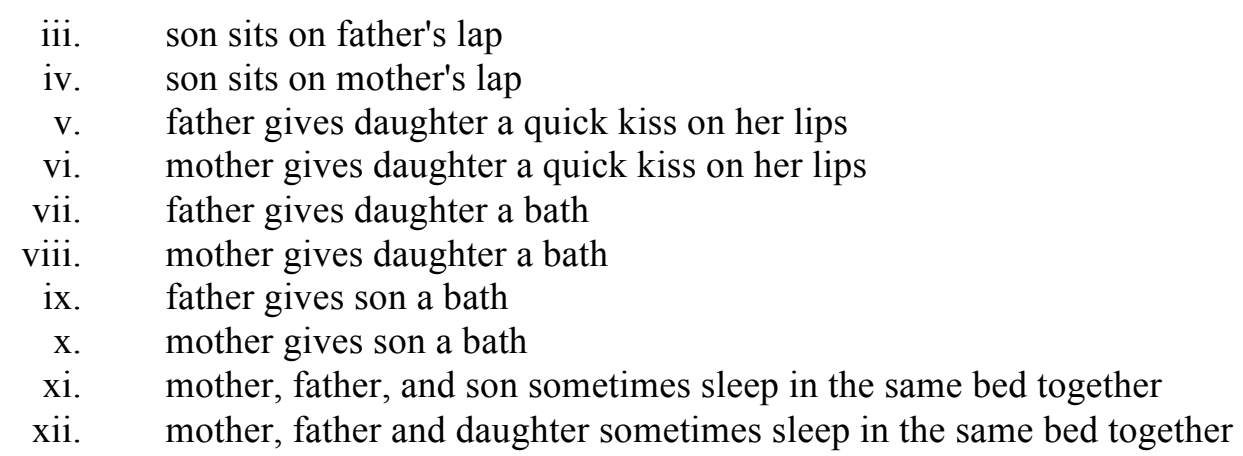

\section{Data Collection}

Data collection was conducted from June 2016 to September 2016. We accessed a private database of a Chinese network technology company which ran a network marketing platform providing online shopping services to 35,120 students from 35 universities or colleges in Beijing. The company had a list of all its customers, including students' names, telephone numbers and shopping accounts. A professional IT staff randomly selected 1,000 students from the customer database and gave a code to each student. Two investigators who were MSW students working under the direction of the principle investigator called 1,000 students with 976 students answering the calls. After a basic introduction about the objectives and procedures of the research, the investigators invited students to participate in the survey online. If a student agreed to do so, an investigator sent a link of the online questionnaire to him or her via text.

Ethical clearance to conduct this study was obtained from the Smith College IRB. After a participant entered the link, he or she was informed of their rights as research subjects. Only after reading the informed consent, and clicking the button "Agree", could the participant answer the survey. All individuals who consented to participate were informed that they were free to withdraw from the project at any point without prejudice. Once they withdrew, we would destroy all of their data. Each student who completed the survey had $\$ 10$ added to their online shopping account. As a result, 354 participants completed the online-based survey. As a result, 354 students in total completed the onlinebased survey.

\section{Data Analysis}

Data was analyzed using SPSS 22. Chi-square tests were used to assess the statistical significance of associations among demographic characteristics of participants and their childhood experiences and perceptions. Factorial repeated-measures ANOVA tests were used to examine the statistical significance of the effect of repeated-measures factors on the perceptions of the appropriateness of parent-child interactions. We calculated a score (ranged from 1to 5) for representing respondents' perceptions of each situation - lap-sitting, kissing, co-bathing, and co-sleeping - by averaging their ratings for the age of children $(2,6,10,14$ and 17). A situation of IPCI was considered as more acceptable when there was a higher score. One-way ANOVA tests were used to examine the impact of childhood experiences of co-bathing and co-sleeping and their perceptions of intra-familial CSA on respondent's perceptions of IPCI.

\section{Results}

\section{Recollections of Childhood Experiences of IPCI}

IPCI were very common among Chinese undergraduate students during childhood (Table 2), including co-sleeping with both mother $(90.4 \%)$ and father $(76.8 \%)$, and co-bathing with mother $(58.8 \%)$ and father $(36.2 \%)$. Chi-square tests reported significant gender differences in their experiences. Respondents reported having more experiences of co-bathing or co-sleeping with the same gender parent than different genders. Male and female respondents were also significantly different regarding 
the age of the last time of co-bathing with both mothers $\left(X^{2}=85.746, p<0.001\right)$ and fathers $\left(X^{2}=\right.$ $21.203, p<0.001)$. Most male respondents $(86.7 \%)$ reported that they ended co-bathing with mothers before 6 years old, but $42.9 \%$ female respondents reported co-bathing with mothers between up to 15 and 17 years old. Childhood experiences of IPCI were not associated with other demographic factors including age, ethnicity, and monthly expenses.

Table 2: Childhood Experiences of IPCI (n/\%; $N=354)$

\begin{tabular}{lllll}
\hline & Total & Male & Female & $\boldsymbol{X}^{2}$ \\
Co-bathing w M & $208 / 58.8$ & $75 / 42.9$ & $133 / 74.3$ & $36.105^{* * *}$ \\
$0-2$ & $39 / 18.8$ & $30 / 40.0$ & $9 / 6.8$ & $85.746^{* * *}$ \\
$3-6$ & $57 / 27.4$ & $35 / 46.7$ & $22 / 16.5$ & \\
$7-10$ & $37 / 17.8$ & $9 / 12.0$ & $28 / 21.1$ & \\
$11-14$ & $18 / 8.7$ & $1 / 1.3$ & $17 / 12.8$ & \\
$15-17$ & $57 / 27.4$ & $0 / 0.0$ & $57 / 42.9$ & \\
Co-bathing w F & $128 / 36.2$ & $120 / 68.6$ & $8 / 4.5$ & $157.515^{* * *}$ \\
$0-2$ & $8 / 6.4$ & $5 / 4.2$ & $3 / 37.5$ & $21.203^{* * *}$ \\
$3-6$ & $17 / 13.5$ & $14 / 11.9$ & $3 / 37.5$ & \\
$7-10$ & $35 / 27.8$ & $33 / 28.0$ & $2 / 25.0$ & \\
$11-14$ & $21 / 16.7$ & $21 / 17.8$ & $0 / 0.0$ & \\
$15-17$ & $45 / 35.7$ & $45 / 28.1$ & $0 / 0.0$ & \\
Co-sleeping w M & $320 / 90.4$ & $155 / 88.6$ & $165 / 92.2$ & 1.326 \\
$0-2$ & $19 / 6.0$ & $13 / 8.5$ & $6 / 3.7$ & $72.604^{* * *}$ \\
$3-6$ & $59 / 18.6$ & $41 / 26.8$ & $18 / 11.0$ & \\
$7-10$ & $78 / 24.6$ & $50 / 32.7$ & $28 / 17.1$ & \\
$11-14$ & $37 / 11.7$ & $26 / 17.0$ & $11 / 6.7$ & \\
$15-17$ & $124 / 39.1$ & $23 / 15.0$ & $101 / 61.6$ & \\
Co-sleeping w F & $272 / 76.8$ & $142 / 81.1$ & $130 / 72.6$ & 3.607 \\
$0-2$ & $19 / 7.17$ & $6 / 4.3$ & $13 / 10.4$ & 5.262 \\
$3-6$ & $62 / 23.4$ & $32 / 22.9$ & $30 / 24.0$ & \\
$7-10$ & $79 / 29.8$ & $40 / 28.6$ & $39 / 31.2$ & \\
$11-14$ & $39 / 14.7$ & $23 / 16.4$ & $16 / 12.8$ & \\
$15-17$ & $66 / 24.9$ & $39 / 27.9$ & $27(21.6$ & \\
\hline$N 0$ - & & & & \\
\hline
\end{tabular}

Note: $* * * p<.001$

\section{Perceptions regarding the Appropriateness of IPCI}

Factors including the child's age child gender, and the parent' gender involved in parent-child interactions were found to impact respondents' perceptions to the appropriateness of those interactions (Table 3). First, there was a significant main effect $(p<.0001)$ of a child's age on ratings of appropriateness of lap-sitting, $F(4,1412)=855.47$; kissing, $F(4,1412)=746.87$; co-bathing, $F(4$, $1412)=1107.61$; and co-sleeping, $F(4,350)=1163.715$. Respondents' ratings of the appropriateness of each of four possible parent-child interactions were lower as children became older. Second, the significant main effect $(p<.0001)$ of a child's gender was found for respondents' perceptions of the appropriateness of all four types of parent-child interactions. Respondents' ratings of the appropriateness of lap-sitting, $F(1,353)=62.24$, and kissing, $F(1,353)=155.25$, were lower for boys than girls; however, for co-bathing, $F(1,353)=57.15$, and co-sleeping, $F(1,353)=29.293$, ratings of the appropriateness were higher for boys than girls. Third, there was also a significant main effect $(p<$ $.0001)$ of parent gender on ratings of appropriateness of lap-sitting, $F(1,353)=116.69$; kissing, $F(1$, 
$353)=232.76$; and co-bathing, $F(1,353)=222.51$. Ratings of the appropriateness were lower for fathers than mothers for each of the three parent-child interactions.

Table 3: Mean Approval Ratings for IPCI

by Child Age, Child Gender, and Parent Gender $(N=354)$

\begin{tabular}{lllll}
\hline & Lap-sitting & Kissing & Co-bathing & Co-sleeping \\
\hline Child age & $F(4,1412)=$ & $F(4,1412)=$ & $F(4,1412)=$ & $F(4,350)=$ \\
& $855.47^{* * *}$ & $746.87^{* * *}$ & $1107.61^{* * *}$ & $1163.715^{* * *}$ \\
2 & 4.50 & 4.25 & 4.35 & 4.35 \\
6 & 4.27 & 3.81 & 3.90 & 3.91 \\
10 & 3.70 & 3.11 & 3.05 & 3.05 \\
14 & 3.02 & 2.58 & 2.44 & 2.37 \\
17 & 2.48 & 2.25 & 2.08 & 1.96 \\
Child & $F(1,353)=$ & $F(1,353)=$ & $F(1,353)=$ & $F(1,353)=$ \\
gender & $62.24^{* * *}$ & $155.25^{* * *}$ & $57.15^{* * *}$ & $29.293^{* * *}$ \\
Boys & 3.48 & 3.01 & $\mathrm{M}=3.25$ & 3.20 \\
Girls & 3.71 & 3.39 & $\mathrm{M}=3.08$ & 3.05 \\
Parent & $F(1,353)=$ & $F(1,353)=$ & $F(1,353)=$ & - \\
gender & $116.69^{* * *}$ & $232.76^{* * *}$ & $222.51^{* * *}$ & \\
Father & 3.48 & 3.01 & 3.00 & - \\
Mother & 3.72 & 3.39 & 3.33 & - \\
\hline
\end{tabular}

Note: $* * * p<.001$

For the appropriateness of lap-sitting, kissing, and co-bathing, significance was also reached for all two-way interactions (i.e., Child Gender $\times$ Child Age, Parent Gender $\times$ Child Age, and Child Gender $\times$ Parent Gender). Although the appropriateness of lap-sitting and kissing declined with age for both boys and girls, the Child Age $\times$ Child Gender interaction suggested that the appropriateness declined more rapidly for boys than for girls. Although there is a decline in appropriateness for each of the three parent-child interactions for either parent as age increases, the Child Age $\times$ Parent Gender interaction indicated that the decline in appropriateness was more severe for fathers than for mothers. For the appropriateness of either lap-sitting or co-bathing, the Parent Gender x Child Gender interactions suggested that same-sex interactions were more approved of than opposite-sex interactions. However, for both parents, kissing boys was less approved of than kissing girls. But for the appropriateness of cosleeping, the significant effect of child age $\times$ child gender interaction was not found (Table 4 ).

Table 4: Mean Approval Ratings for IPCI (Two-Way Interactions; $N=354$ )

\begin{tabular}{llllll}
\hline \multirow{2}{*}{$\begin{array}{l}\text { Child gender } \times \text { Child } \\
\text { age }\end{array}$} & Lap-sitting & Kissing & Co-bathing & Co-sleeping \\
\cline { 3 - 6 } & $F(4,1412)=$ & $F(4,1412)=$ & $F(4,1412)=$ & $F(4,350)=$ \\
\hline Boys & $29.54^{* * *}$ & $10.22^{* * *}$ & $9.28^{* * *}$ & 2.468 \\
& 2 & 4.48 & 4.14 & 4.42 & 4.36 \\
& 6 & 4.23 & 3.62 & 4.05 & 3.98 \\
& 10 & 3.60 & 2.89 & 3.17 & 3.19 \\
\multirow{6}{*}{ Girls } & 14 & 2.84 & 2.36 & 2.50 & 2.45 \\
& 17 & 2.28 & 2.04 & 2.11 & 2.01 \\
& 2 & 4.52 & 4.35 & 4.28 & 4.33 \\
& 6 & 4.31 & 3.99 & 3.75 & 3.83 \\
& 10 & 3.80 & 3.34 & 2.93 & 2.90 \\
& 14 & 3.22 & 2.80 & 2.28 & 2.29 \\
& 17 & 2.69 & 2.46 & 2.04 & 1.90 \\
\hline
\end{tabular}




\begin{tabular}{|c|c|c|c|c|c|}
\hline \multicolumn{2}{|c|}{$\begin{array}{l}\text { Parent gender } \times \text { Child } \\
\text { age }\end{array}$} & \multirow{2}{*}{$\begin{array}{l}\mathrm{F}(4,1412)= \\
17.90^{* * *} \\
4.45\end{array}$} & \multirow{2}{*}{$\begin{array}{l}\mathrm{F}(4,1412)= \\
36.98 * * * \\
4.26\end{array}$} & \multirow{2}{*}{$\begin{array}{l}\mathrm{F}(4,1412)= \\
17.20^{* * *} \\
4.19\end{array}$} & \multirow{2}{*}{ - } \\
\hline Father & 2 & & & & \\
\hline & 6 & 4.19 & 3.68 & 3.65 & - \\
\hline & 10 & 3.58 & 2.82 & 2.88 & - \\
\hline & 14 & 2.86 & 2.56 & 2.32 & - \\
\hline & 17 & 2.31 & 1.96 & 1.99 & - \\
\hline \multirow[t]{5}{*}{ Mother } & 2 & 4.55 & 4.44 & 4.29 & - \\
\hline & 6 & 4.35 & 4.12 & 3.97 & - \\
\hline & 10 & 3.83 & 3.28 & 3.35 & - \\
\hline & 14 & 3.19 & 2.63 & 2.84 & - \\
\hline & 17 & 2.66 & 2.19 & 2.51 & - \\
\hline \multicolumn{2}{|c|}{$\begin{array}{l}\text { Child gender } \times \text { Parent } \\
\text { gender }\end{array}$} & $\begin{array}{l}\mathrm{F}(1,353)= \\
213.09 * * *\end{array}$ & $\begin{array}{l}\mathrm{F}(1,353)= \\
70.32^{* * * *}\end{array}$ & $\begin{array}{l}\mathrm{F}(1,353)= \\
498.43^{* * *}\end{array}$ & - \\
\hline \multirow[t]{2}{*}{ Boys } & Father & 3.56 & 3.43 & 2.91 & - \\
\hline & Mother & 3.41 & 3.06 & 3.10 & - \\
\hline \multirow[t]{2}{*}{ Girls } & Father & 3.40 & 2.56 & 3.10 & - \\
\hline & Mother & 4.02 & 3.60 & 3.68 & - \\
\hline
\end{tabular}

The three-way interactions between child age, child gender, and parent gender was significant $(p<$ .0001 ) for the appropriateness of lap-sitting, $F(4,1412)=61.17$; kissing, $F(4,1412)=35.94$; and cobathing $F(4,1412)=79.907$ (Table 5). First, ratings of the appropriateness declined as age increased no matter the type of parent-child interactions, child gender, and parent gender. Second, regardless of the parent gender or child age, lap-sitting with or kissing girls was more approved of than for boys; and bathing girls was less approved of than bathing boys. Third, no mater the age and gender of children, the ratings of the appropriateness were lower for fathers than for mothers for each of three types of parent-child interactions. Fourth, lap-sitting was the most acceptable type of IPCI, and kissing sons was least acceptable and lap-sitting by daughters was most acceptable.

Table 5: Mean Approval Ratings for IPCI (Three-Way Interactions; $N=354$ )

\begin{tabular}{lcccccc}
\hline & Age & \multicolumn{2}{c}{ Fathers } & \multicolumn{2}{c}{ Mothers } & \multirow{2}{*}{$\begin{array}{c}\text { Within-Subject } \\
\text { Effects }\end{array}$} \\
\cline { 3 - 6 } & & Boys & Girls & Boys & Girls & \\
\hline Lap- & 2 & 4.47 & 4.43 & 4.48 & 4.62 & F $(4,1412)=$ \\
Sitting & & & & & & $61.17^{* * *}$ \\
& 6 & 4.25 & 4.12 & 4.20 & 4.50 & \\
& 10 & 3.70 & 3.45 & 3.50 & 4.15 & \\
& 14 & 2.96 & 2.77 & 2.72 & 3.66 & \\
& 17 & 2.39 & 2.22 & 2.17 & 3.16 & \\
\hline Kissing & 2 & 4.08 & 4.31 & 4.20 & 4.40 & F $(4,1412)=$ \\
& 6 & 3.49 & 3.80 & 3.75 & 4.18 & \\
& 10 & 2.77 & 2.99 & 3.00 & 3.69 & \\
& 14 & 2.26 & 2.38 & 2.45 & 3.22 & \\
& 17 & 1.97 & 2.02 & 2.11 & 2.90 & \\
\hline Bathing & 2 & 4.44 & 4.08 & 4.40 & 4.48 & F $(4,1412)=$ \\
& 6 & 4.13 & 3.23 & 3.96 & 4.27 & \\
& 10 & 3.43 & 2.20 & 2.90 & 3.66 & \\
\hline
\end{tabular}




\begin{tabular}{rrrrr}
\hline 14 & 2.78 & 1.74 & 2.23 & 3.03 \\
17 & 2.40 & 1.51 & 1.82 & 2.57 \\
\hline Note $* * * *<001$ & & &
\end{tabular}

Note: $* * * p<.001$

\section{Perceptions of Ages up to IPCI}

Many respondents perceived that there should be a limited age range for IPCI. For example, most respondents thought all situations of IPCI were appropriate when the child was 6 years old or less (Table 6). However, $72.7 \%$ of respondents indicated that bathing a daughter by a father was inappropriate when a girl was 10 years old. When the child was 14 years old, more situations of IPCI were perceived as inappropriate by more than half of respondents. For example, $66.1 \%$ of respondents thought kissing a son by a father was inappropriate when a boy was 14 years. More than $60 \%$ of respondents perceived that co-sleeping with parents was inappropriate when a child was 14 years old. When a child was 17 years old, more than half of respondents believed that most listed types of IPCI were inappropriate except for two situations: a daughter sitting on a mother's lap and mother's giving her daughter a quick kiss on the lips.

Table 6: Perceptions of Ages Up to IPCI (n/\%; $N=354)$

\begin{tabular}{llllll}
\hline & 2 years & 6 years & 10 years & 14 years & 17 years \\
\hline Lap-sitting G \& F & $8 / 2.3$ & $17 / 4.8$ & $72 / 20.3$ & $167 / 47.2$ & $237 / 66.7$ \\
Lap-sitting G \& M & $3 / 0.8$ & $3 / 0.8$ & $17 / 4.8$ & $66 / 18.6$ & $129 / 36.4$ \\
Lap-sitting B \& F & $12 / 3.4$ & $16 / 4.5$ & $61 / 17.2$ & $147 / 41.5$ & $228 / 64.4$ \\
Lap-sitting B \& M & $12 / 3.4$ & $17 / 4.8$ & $74 / 20.9$ & $178 / 50.3$ & $247 / 69.8$ \\
Kissing G \& F & $21 / 5.9$ & $48 / 13.6$ & $143 / 40.4$ & $219 / 61.9$ & $265 / 74.9$ \\
Kissing G \& M & $16 / 4.5$ & $27 / 7.6$ & $61 / 17.2$ & $112 / 31.6$ & $150 / 42.4$ \\
Kissing B \& F & $41 / 11.6$ & $78 / 22.0$ & $168 / 47.5$ & $234 / 66.1$ & $262 / 74.0$ \\
Kissing B \& M & $28 / 7.9$ & $51 / 14.4$ & $133 / 37.6$ & $20 / 59.0$ & $247 / 69.8$ \\
Co-bathing G \& F & $29 / 8.2$ & $102 / 28.8$ & $255 / 72.0$ & $306 / 86.4$ & $321 / 90.7$ \\
Co-bathing G \& M & $11 / 3.1$ & $17 / 4.8$ & $64 / 18.1$ & $140 / 39.5$ & $194 / 54.8$ \\
Co-bathing B \& F & $10 / 2.8$ & $23 / 6.5$ & $81 / 22.9$ & $165 / 46.6$ & $209 / 59.0$ \\
Co-bathing B \& M & $9 / 2.5$ & $26 / 7.3$ & $131 / 37.0$ & $246 / 69.5$ & $286 / 80.8$ \\
Co-sleeping G & $16 / 4.5$ & $39 / 11.0$ & $131 / 37.0$ & $236 / 66.7$ & $269 / 76.0$ \\
Co-sleeping B & $16 / 4.5$ & $31 / 8.8$ & $96 / 27.1$ & $218 / 61.6$ & $258 / 72.9$ \\
\hline
\end{tabular}

Note: $\mathrm{G}=$ Girls, $\mathrm{B}=$ Boys, $\mathrm{F}=$ Father, $\mathrm{M}=$ Mother

\section{Childhood Experiences of IPCI and Perceptions}

Respondents who had experiences of co-bathing or co-sleeping with parents during childhood showed significantly more acceptance to situations of IPCI than those who did not have such experiences (Table 7). For example, compared to those who did not have experiences of co-bathing with mother (Mean $=3.42, S D=.83)$, respondents who had such experiences (Mean $=3.73, S D=.79$ ) showed significantly more acceptance of the situation of "mother gives daughter a bath", $F(1,352)=13.322$, $p<.001$.

Table 7: Childhood Experiences of IPCI and Perceptions

\begin{tabular}{|c|c|c|c|c|c|c|c|c|c|c|c|c|}
\hline & \multicolumn{3}{|c|}{ Co-bathing with $\mathrm{M}$} & \multicolumn{3}{|c|}{ Co-bathing with F } & \multicolumn{3}{|c|}{ Co-sleeping with $\mathrm{M}$} & \multicolumn{3}{|c|}{ Co-sleeping with F } \\
\hline & 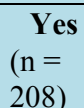 & 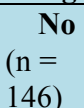 & $\begin{array}{l}F(1, \\
352)\end{array}$ & $\begin{array}{c}\text { Yes } \\
(\mathrm{n}= \\
128)\end{array}$ & $\begin{array}{c}\text { No } \\
(\mathrm{n}= \\
226)\end{array}$ & $\begin{array}{l}F(1, \\
352)\end{array}$ & 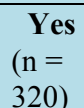 & $\begin{array}{l}\quad \text { No } \\
(\mathrm{n}= \\
34)\end{array}$ & $\begin{array}{l}\boldsymbol{F}(1, \\
352)\end{array}$ & $\begin{array}{c}\text { Yes } \\
(\mathrm{n}= \\
272)\end{array}$ & $\begin{array}{l}\text { No } \\
(\mathrm{n}= \\
82)\end{array}$ & $\begin{array}{l}F(1, \\
352)\end{array}$ \\
\hline & $\begin{array}{l}\text { Mean } \\
\text { (sd) }\end{array}$ & $\begin{array}{l}\text { Mean } \\
\text { (sd) }\end{array}$ & $\begin{array}{l}\text { ANO } \\
\text { VA }\end{array}$ & $\begin{array}{l}\text { Mean } \\
\text { (sd) }\end{array}$ & $\begin{array}{l}\text { Mean } \\
\text { (sd) }\end{array}$ & $\begin{array}{l}\text { ANO } \\
\text { VA }\end{array}$ & $\begin{array}{l}\text { Mean } \\
\text { (sd) }\end{array}$ & $\begin{array}{l}\text { Mean } \\
\text { (sd) }\end{array}$ & $\begin{array}{l}\text { ANO } \\
\text { VA }\end{array}$ & $\begin{array}{l}\text { Mean } \\
\text { (sd) }\end{array}$ & $\begin{array}{l}\text { Mean } \\
\text { (sd) }\end{array}$ & $\begin{array}{l}\text { ANO } \\
\text { VA }\end{array}$ \\
\hline $\begin{array}{l}\text { Lap- } \\
\text { sitting } \\
\text { G\&F }\end{array}$ & $\begin{array}{l}3.39 \\
(.82)\end{array}$ & $\begin{array}{l}3.41 \\
(.89)\end{array}$ & 0.035 & $\begin{array}{l}3.52 \\
(.82)\end{array}$ & $\begin{array}{l}3.32 \\
(.85)\end{array}$ & $\begin{array}{l}4.529 \\
*\end{array}$ & $\begin{array}{l}3.44 \\
(.82)\end{array}$ & $\begin{array}{l}2.97 \\
(.98)\end{array}$ & $\begin{array}{l}9.741 \\
* *\end{array}$ & $\begin{array}{l}3.50 \\
(.83)\end{array}$ & $\begin{array}{l}3.06 \\
(.83)\end{array}$ & $\begin{array}{l}17.49 \\
9 * * *\end{array}$ \\
\hline
\end{tabular}




\begin{tabular}{|c|c|c|c|c|c|c|c|c|c|c|c|c|}
\hline $\begin{array}{l}\text { Lap- } \\
\text { sitting } \\
\text { G\&M }\end{array}$ & $\begin{array}{l}4.08 \\
(.73)\end{array}$ & $\begin{array}{l}3.93 \\
(.83)\end{array}$ & 2.933 & $\begin{array}{l}4.07 \\
(.77)\end{array}$ & $\begin{array}{l}3.99 \\
(.78)\end{array}$ & 0.807 & $\begin{array}{l}4.07 \\
(.75)\end{array}$ & $\begin{array}{l}3.58 \\
(.87)\end{array}$ & $\begin{array}{l}12.65 \\
7 * * *\end{array}$ & $\begin{array}{l}4.05 \\
(.75)\end{array}$ & $\begin{array}{l}3.90 \\
(.83)\end{array}$ & 2.601 \\
\hline $\begin{array}{l}\text { Lap- } \\
\text { sitting } \\
\text { B\&F }\end{array}$ & $\begin{array}{l}3.59 \\
(.85)\end{array}$ & $\begin{array}{l}3.51 \\
(.85)\end{array}$ & 0.841 & $\begin{array}{l}3.58 \\
(.87)\end{array}$ & $\begin{array}{l}3.54 \\
(.83)\end{array}$ & 0.132 & $\begin{array}{l}3.59 \\
(.85)\end{array}$ & $\begin{array}{l}3.18 \\
(.78)\end{array}$ & $\begin{array}{l}7.397 \\
* *\end{array}$ & $\begin{array}{l}3.63 \\
(.85)\end{array}$ & $\begin{array}{l}3.31 \\
(.80)\end{array}$ & $\begin{array}{l}8.943 \\
* *\end{array}$ \\
\hline $\begin{array}{l}\text { Lap- } \\
\text { sitting } \\
\text { B\&M }\end{array}$ & $\begin{array}{l}3.44 \\
(.77)\end{array}$ & $\begin{array}{l}3.37 \\
(.79)\end{array}$ & 0.663 & $\begin{array}{l}3.46 \\
(.81)\end{array}$ & $\begin{array}{l}3.39 \\
(.76)\end{array}$ & 0.777 & $\begin{array}{l}3.45 \\
(.77)\end{array}$ & $\begin{array}{l}3.04 \\
(.76)\end{array}$ & $\begin{array}{l}8.866 \\
* *\end{array}$ & $\begin{array}{l}3.47 \\
(.78)\end{array}$ & $\begin{array}{l}3.22 \\
(.73)\end{array}$ & $\begin{array}{l}6.986 \\
* *\end{array}$ \\
\hline $\begin{array}{l}\text { Kissing } \\
\text { G\&F }\end{array}$ & $\begin{array}{l}3.09 \\
(.78)\end{array}$ & $\begin{array}{l}3.11 \\
(.94)\end{array}$ & 0.035 & $\begin{array}{l}3.23 \\
(.82)\end{array}$ & $\begin{array}{l}3.03 \\
(.86)\end{array}$ & $\begin{array}{l}4.747 \\
*\end{array}$ & $\begin{array}{l}3.11 \\
(.86)\end{array}$ & $\begin{array}{l}2.91 \\
(.77)\end{array}$ & 1.834 & $\begin{array}{l}3.14 \\
(.86)\end{array}$ & $\begin{array}{l}2.97 \\
(.80)\end{array}$ & 2.642 \\
\hline $\begin{array}{l}\text { Kissing } \\
\text { G\&M }\end{array}$ & $\begin{array}{l}3.70 \\
(.87)\end{array}$ & $\begin{array}{l}3.65 \\
(.94)\end{array}$ & 0.324 & $\begin{array}{l}3.87 \\
(.85)\end{array}$ & $\begin{array}{l}3.57 \\
(.91)\end{array}$ & $\begin{array}{l}9.123 \\
* *\end{array}$ & $\begin{array}{l}3.69 \\
(.90)\end{array}$ & $\begin{array}{l}3.56 \\
(.87)\end{array}$ & 0.672 & $\begin{array}{l}3.71 \\
(.92)\end{array}$ & $\begin{array}{l}3.58 \\
(.83)\end{array}$ & 1.415 \\
\hline $\begin{array}{l}\text { Kissing } \\
\text { B\&F }\end{array}$ & $\begin{array}{l}2.98 \\
(.83)\end{array}$ & $\begin{array}{l}2.82 \\
(.93)\end{array}$ & 2.884 & $\begin{array}{l}2.93 \\
(.86)\end{array}$ & $\begin{array}{l}2.90 \\
(.88)\end{array}$ & 0.077 & $\begin{array}{l}2.92 \\
(.89)\end{array}$ & $\begin{array}{l}2.89 \\
(.68)\end{array}$ & 0.033 & $\begin{array}{l}2.91 \\
(.91)\end{array}$ & $\begin{array}{l}2.92 \\
(.72)\end{array}$ & 0.015 \\
\hline $\begin{array}{l}\text { Kissing } \\
\text { B\&M }\end{array}$ & $\begin{array}{l}3.15 \\
(.85)\end{array}$ & $\begin{array}{l}3.03 \\
(.88)\end{array}$ & 1.591 & $\begin{array}{l}3.18 \\
(.87)\end{array}$ & $\begin{array}{l}3.06 \\
(.86)\end{array}$ & 1.649 & $\begin{array}{l}3.12 \\
(.88)\end{array}$ & $\begin{array}{l}2.91 \\
(.69)\end{array}$ & 1.836 & $\begin{array}{l}3.10 \\
(.90)\end{array}$ & $\begin{array}{l}3.11 \\
(.72)\end{array}$ & 0.016 \\
\hline $\begin{array}{l}\text { Co- } \\
\text { bathing } \\
\text { G\&F }\end{array}$ & $\begin{array}{l}2.57 \\
(.66)\end{array}$ & $\begin{array}{l}2.53 \\
(.69)\end{array}$ & 0.332 & $\begin{array}{l}2.69 \\
(.71)\end{array}$ & $\begin{array}{l}2.48 \\
(.65)\end{array}$ & $\begin{array}{l}7.729 \\
* *\end{array}$ & $\begin{array}{l}2.57 \\
(.68)\end{array}$ & $\begin{array}{l}2.45 \\
(.59)\end{array}$ & 0.858 & $\begin{array}{l}2.59 \\
(.67)\end{array}$ & $\begin{array}{l}2.43 \\
(.66)\end{array}$ & 3.441 \\
\hline $\begin{array}{l}\text { Co- } \\
\text { bathing } \\
\text { G\&M }\end{array}$ & $\begin{array}{l}3.73 \\
(.79)\end{array}$ & $\begin{array}{l}3.42 \\
(.83)\end{array}$ & $\begin{array}{l}13.32 \\
2 * * *\end{array}$ & $\begin{array}{l}3.73 \\
(.81)\end{array}$ & $\begin{array}{l}3.53 \\
(.82)\end{array}$ & $\begin{array}{l}4.554 \\
*\end{array}$ & $\begin{array}{l}3.65 \\
(.80)\end{array}$ & $\begin{array}{l}3.21 \\
(.91)\end{array}$ & $\begin{array}{l}8.738 \\
* *\end{array}$ & $\begin{array}{l}3.65 \\
(.83)\end{array}$ & $\begin{array}{l}3.44 \\
(.76)\end{array}$ & $\begin{array}{l}4.314 \\
*\end{array}$ \\
\hline $\begin{array}{l}\text { Co- } \\
\text { bathing } \\
\text { B\&F }\end{array}$ & $\begin{array}{l}3.56 \\
(.79)\end{array}$ & $\begin{array}{l}3.25 \\
(.80)\end{array}$ & $\begin{array}{l}12.89 \\
7 * * *\end{array}$ & $\begin{array}{l}3.66 \\
(.80)\end{array}$ & $\begin{array}{l}3.31 \\
(.79)\end{array}$ & $\begin{array}{l}15.97 \\
2 * * *\end{array}$ & $\begin{array}{l}3.47 \\
(.79)\end{array}$ & $\begin{array}{l}3.07 \\
(.87)\end{array}$ & $\begin{array}{l}7.776 \\
* *\end{array}$ & $\begin{array}{l}3.51 \\
(.81)\end{array}$ & $\begin{array}{l}3.17 \\
(.74)\end{array}$ & $\begin{array}{l}11.49 \\
4 * *\end{array}$ \\
\hline $\begin{array}{l}\text { Co- } \\
\text { bathing } \\
\text { B\&M }\end{array}$ & $\begin{array}{l}3.14 \\
(.60)\end{array}$ & $\begin{array}{l}2.94 \\
(.66)\end{array}$ & $\begin{array}{l}8.992 \\
* *\end{array}$ & $\begin{array}{l}3.10 \\
(.67)\end{array}$ & $\begin{array}{l}3.04 \\
(.61)\end{array}$ & 0.640 & $\begin{array}{l}3.10 \\
(.61)\end{array}$ & $\begin{array}{l}2.75 \\
(.74)\end{array}$ & $\begin{array}{l}9.249 \\
* *\end{array}$ & $\begin{array}{l}3.11 \\
(.64)\end{array}$ & $\begin{array}{l}2.91 \\
(.58)\end{array}$ & $\begin{array}{l}5.942 \\
*\end{array}$ \\
\hline $\begin{array}{l}\text { Co- } \\
\text { sleeping } \\
\text { G }\end{array}$ & $\begin{array}{l}3.06 \\
(.73)\end{array}$ & $\begin{array}{l}3.03 \\
(.78)\end{array}$ & 0.129 & $\begin{array}{l}3.09 \\
(.76)\end{array}$ & $\begin{array}{l}3.03 \\
(.75)\end{array}$ & 0.500 & $\begin{array}{l}3.08 \\
(.75)\end{array}$ & $\begin{array}{l}2.77 \\
(.68)\end{array}$ & $\begin{array}{l}5.287 \\
*\end{array}$ & $\begin{array}{l}3.14 \\
(.74)\end{array}$ & $\begin{array}{l}2.74 \\
(.72)\end{array}$ & $\begin{array}{l}18.97 \\
3 * * *\end{array}$ \\
\hline $\begin{array}{l}\text { Co- } \\
\text { sleeping } \\
\text { B }\end{array}$ & $\begin{array}{l}3.26 \\
(.76)\end{array}$ & $\begin{array}{l}3.12 \\
(.80)\end{array}$ & 2.817 & $\begin{array}{l}3.26 \\
(.79)\end{array}$ & $\begin{array}{l}3.16 \\
(.77)\end{array}$ & 1.389 & $\begin{array}{l}3.23 \\
(.77)\end{array}$ & $\begin{array}{l}2.82 \\
(.80)\end{array}$ & $\begin{array}{l}8.886 \\
* *\end{array}$ & $\begin{array}{l}3.27 \\
(.79)\end{array}$ & $\begin{array}{l}2.95 \\
(.70)\end{array}$ & $\begin{array}{l}11.23 \\
2 * *\end{array}$ \\
\hline
\end{tabular}

Note: $\mathrm{G}=$ Girls, $\mathrm{B}=$ Boys, $\mathrm{F}=$ Father, $\mathrm{M}=$ Mother

$* p<.05, * * p<.01, * * * p<.001$

\section{Perceptions of Intra-Familial CSA}

More than half of respondents (60.7\%) agreed that a child might be sexually abused by his or her parent. However, $39.3 \%$ respondents still believed that it is impossible for parents to be perpetrators of CSA. Chi-square tests reported that respondents' perceptions of intra-familial CSA were not associated with their demographic characteristics. We also found a significant impact for respondents' understanding of intra-familial CSA on their perceptions of lap-sitting, kissing, co-bathing, and cosleeping between parents and children. Generally, respondents who agreed that parents might be perpetrators of CSA showed less acceptance of situations of parent-child intimate interactions than those who disagreed (Table 8). For example, comparing those who admitted the possibility of a child being sexually abused by his or her parent (Mean $=2.99, S D=.83$ ) to respondents who denied the possibility (Mean $=3.36, S D=.86$ ), the latter showed significantly more acceptance of the situation "father gives daughter a quick kiss on her lips", $F(2,352)=8.517, p<.01$.

Table 8. Perceptions of Intra-Familial CSA

\begin{tabular}{llll}
\hline & $\begin{array}{c}\text { Agree } \\
(\mathrm{n}=215)\end{array}$ & $\begin{array}{c}\text { Disagree } \\
(\mathrm{n}=139)\end{array}$ & $\boldsymbol{F}(2,352)$ \\
\cline { 2 - 4 } & Mean $(\mathrm{sd})$ & Mean $(\mathrm{sd})$ & ANOVA \\
\hline Lap-sitting G \& F & $3.35(.83)$ & $3.47(.87)$ & 1.671 \\
Lap-sitting G \& M & $3.96(.80)$ & $4.10(.73)$ & 2.623 \\
Lap-sitting B \& F & $3.48(.84)$ & $3.68(.85)$ & $4.751^{*}$ \\
Lap-sitting B \& M & $3.36(.75)$ & $3.49(.82)$ & 2.146 \\
Kissing G \& F & $2.99(.83)$ & $3.36(.86)$ & $8.517^{* *}$ \\
\hline
\end{tabular}




\begin{tabular}{llll}
\hline Kissing G \& M & $3.63(.93)$ & $3.75(.84)$ & 1.353 \\
Kissing B \& F & $2.79(.87)$ & $3.11(.84)$ & $12.220^{* *}$ \\
Kissing B \& M & $3.02(.85)$ & $3.22(.86)$ & $4.593^{*}$ \\
Co-bathing G \& F & $2.47(.66)$ & $2.69(.68)$ & $9.309^{* *}$ \\
Co-bathing G \& M & $3.57(.82)$ & $3.66(.83)$ & 1.104 \\
Co-bathing B \& F & $3.39(.80)$ & $3.51(.81)$ & 1.822 \\
Co-bathing B \& M & $3.01(.64)$ & $3.14(.62)$ & 3.806 \\
Co-sleeping G & $2.98(.75)$ & $3.16(.75)$ & $4.650^{*}$ \\
Co-sleeping B & $3.12(.77)$ & $3.32(.78)$ & $5.803^{*}$ \\
\hline
\end{tabular}

Note: $\mathrm{G}=$ Girls, $\mathrm{B}=$ Boys, $\mathrm{F}=$ Father, $\mathrm{M}=$ Mother

$* p<.05, * * p<.01$

\section{Discussion}

Interpersonal touching such as IPCI is largely mediated by culture (Dibiase \& Gunnoe, 2004). Most research and writing about CSA has come from Western scholars and thus norms for appropriate and inappropriate IPCI reflect this (Atteberry-Bennett, 1987; Johnson \& Hooper; 2003). Typical or commonly acceptable IPCI in Asian families (with possible national and ethnic differences) may be different from those in middle class white families (Tahhan, 2008). IPCI such as co-sleeping and cobathing with parents during childhood have been considered as an important part of daily life and family practices in most Asian countries (Rothbaum, Morelli, Pott, \& Liu, 2000). In the current study, co-bathing and co-sleeping with parents were very common among Chinese undergraduate students until 18 years of age. More than 1/4 Chinese undergraduate student in the current study still had experiences of co-bathing or co-sleeping with parents when they were 15-17 years old. Although the majority of Chinese undergraduate students perceived that there should be a limited age range for the appropriateness of IPCI, their parameters for IPCI were different from the mean ages that American scholars (e.g., Johnson \& Hooper; 2003) consider discouraging and discontinuing certain IPCI.

This study also found that the age and gender of children, and the gender of parents influenced the perceptions of Chinese undergraduate students about the appropriateness of IPCI (e.g., lap-sitting, kissing, co-bathing, and co-sleeping). The trends were consistent with previous studies in the U.S. (Harrison-Speake and Willis, 1995), which indicated that the rates of appropriateness declined when the child's age getting as the child became older, and interactions for opposite-sex family members were generally considered less acceptable than for same sex pairs.

From an individual point of view, how people are raised by their parents in their family of origin may shape their perceptions regarding IPCI. The study found that respondents' childhood experiences of cobathing or co-sleeping with parents might impact their perceptions of the appropriateness of such interactions. Chinese undergraduate students who have had previous experiences of co-bathing or cosleeping with parents might hold more open attitudes to IPCI. These undergraduate students may raise their children in the same way in the future as they may well have internalized loose or strict family boundaries from their family of origin and often accept these without further consideration (Johnson, 2005).

From a socio-cultural point of view, social norms about acceptable and unacceptable IPCI may have a serious impact not only on how parents evaluate the appropriateness of their interactions with their own children but how a society defines CSA. When the majority of people consider a specific IPCI as acceptable within a socio-cultural context, it will be difficult to define it as intra-familial CSA. Therefore, social norms and the social structures and practices that contribute to the norms surrounding IPCI impact the definition of intra-familial CSA, which still remains an ambiguous issue in both academic research settings and practice (Colin-Vezina, et.al., 2012; Haugaard, 2000). The lack of a common accepted definition makes research, prevention and intervention of intra-familial CSA inherently challenging. Definitions of CSA will continue to be internationally contested and culturally grounded. For example, to decide whether certain behaviors are abusive or not requires setting age parameters for what is and is not appropriate. It is difficult to determine at which point to divide the 
continuum between normal and inappropriate (Haugaard, 2000). Normative or typical IPCI in a given society serves as reference points for professional decisions and even court proceedings regarding intra-familial CSA. The results of the current study may shed some light about the norms regarding acceptable age ranges for IPCI in Chinese society, which may be helpful for professionals when making decisions about child protection. This is particularly important as China is in the early stages of developing a child welfare system.

Similar to Chinese parents in previous studies (Xie et al, 2017), some Chinese undergraduate students preferred to believe that CSA could not happen within the family. "Family-centered" relationships were places where affection among family members is particularly valued. Parents are considered to do everything for their children's good in traditional Chinese culture (Qiao \& Xie, 2017; Xie et al, 2017). However, this "family-centered" value may well obscure intra-familial CSA in Chinese society. The study found that respondents' perceptions of intra-familial CSA might impact their perceptions of the appropriateness of IPCI. People who have higher awareness of intra-familial CSA may have a clearer idea about what constitutes acceptable and unacceptable IPCI. Therefore, improving public awareness and knowledge regarding intra-familial CSA through education programs may be a useful strategy to use in the prevention intra-familial CSA in Chinese society. This, as with all strategies, will rely on defining what is normative and what is abusive.

\section{Limitations}

The current study has some limitations. First, the study opted for a convenience sample of undergraduate students whose opinions might not reflect those of the general public. Since almost all of the undergraduate students were nonparents, their perceptions of the appropriateness of IPCI might be different from those who are parents. Conversely, perceptions of undergraduate students might be more dispassionate than parents since it might be harder for parents to admit that possibility of intra-familial CSA. Undergraduate students might have different opinions related to CSA from professionals who need to make decisions about child protection. Therefore, future research about societal perceptions of IPCI may need a more representative sample of nonstudent populations, including parents and child protective professionals. Also, a self-administered questionnaire, which we developed, was utilized to collect data since this was an explorative study in mainland China. In future research, it may be necessary to develop and use instruments that are seen as being valid by a range of researchers to accurately assess public perceptions of IPCI. Lastly, the study relied on the recollections of young adults without also triangulating the data with other sources, such as those of their parents.

\section{Conclusion}

It is not easy to demarcate when behaviors are abusive or not when involving intimate contact between caregivers and children within families in different sociocultural contexts. Clearly, defining intrafamilial CSA needs to be culturally contextualized. Cultural variations of normal and abnormal IPCI have been minimized or overlooked. This current study assessed perceptions of IPCI in mainland China, in an effort to contribute to our understanding of what is considered normative, which should help with distinguishing when intra-familial CSA occurs. We suggest that better understanding of normal IPCI within a socio-cultural context and comprehensive information and public education about intra-familial CSA are needed for the understanding of and prevention of CSA.

\section{References}

Atteberry-Bennett, J. (1987). Child sexual abuse: Definitions and interventions of parents and professionals. Doctoral dissertation, University of Virginia.

Baker, K.A. \& Dwairy, M. (2003). Cultural norms versus state law in treating incest: a suggested model for Arab families. Child Abuse \& Neglect, 27, 109-123. 
Barber, B.K. \& Thomas, D.L. (1986). Dimensions of fathers' and mothers' supportive behavior: The case for physical affection. Journal of Marriage and Family, 48(4), 783-794.

Berkowitz, A.D. (2003). Applications of social norm theory to other health and social justice issues. In H.W. Perkins (Ed.) The social norm approach to preventing school and college age substance abuse: A handbook for educators, counselors, clinicians (pp. 259-279). NY: JosseyBass Publishers.

Bornstein, B., Kaplan, D., \& Perry, A. (2007). Child abuse in the eyes of the beholder: Lay perceptions of child sexual and physical abuse. Child Abuse and Neglect, 31, 375-391.

Chen, W., \& Jin, X. J. (2016). A study on the status of, reasons for, and solutions to child sexual abuse cases. Issues on Juvenile Crimes and Delinquency, 4, 42-52 (In Chinese).

China Social Assistant Foundation. (2015). The report of child safety education and sexual assaults cases in 2013-2015, the Program of Girls Protection. (In Chinese).

Collin-Vezina, D., Daigenault, I., \& Hebert, M. (2013). Lessons learned from child sexual abuse research: Prevalence, outcomes and preventative strategies. Child and Adolescent Psychiatry and Mental Health, 7(22), 22.

Davies, M. \& Rogers, P. (2009). Perceptions of blame and credibility toward victims of childhood sexual abuse: Differences across victim age, victim-perpetrator relationship, and respondent gender in a depicted case. Journal of Child Sexual Abuse, 18(1), 78-92.

Dibiase, R. \& Gunnoe, J. (2004), Gender and culture differences in touching behavior. The Journal of Social Psychology, 144(1), 49-62.

Friedrich, W.N. (2002). Psychological Assessment of Sexually Abused Children and Their Families. Thousand Oaks, CA: Sage Publications.

Gil, E. \& Johnson, T.C. (1993). Clinical Evaluation. Sexualized Children: Assessment and Treatment of Sexualized Children and Children Who Molest. Rockville, MD: Launch Press.

Giglio, J.J., Wolfteich, P.M., Gabrenya, W.K., \& Sohn, M.L. (2011). Differences in perceptions of child sexual abuse based on perpetrator age and respondent gender. Journal of Child Sexual Abuse, 20(4), 396-412.

Harrison-Speake, K. \& Willis, F.N. (1995). Ratings of the appropriateness of touching among family members. Journal of Nonverbal Behavior. 19(2), 85-100.

Haugaard, J.J. (2000). The Challenge of Defining Child Sexual Abuse. American Psychologist, 55(9), 1036-1039.

Haynes-Seman, C., \&. Krugman, R. (1989). Sexualized attention: Normal interaction or precursor to sexual abuse? American Journal of Orthopsychiatry, 59, 238-245.

Hestick, H. \& Perrino, C.S. (2009) African-American undergraduates' perceptions and attributions of child sexual abuse. Journal of Child Sexual Abuse, 18(1), 61-77.

Ho, T.P., \& Kwok, W.M. (1991). Child sexual abuse in Hong Kong. Child Abuse \& Neglect, 15, $597-$ 600.

Hyson, M. C., Whitehead, L. C. \& Prudhoe, C. M. (1988). Influences on attitudes toward physical affections between adults and children. Early Childhood Research Quarterly, 3 55-75.

Ji, K., Finkelhor, D., \& Dunne, M.P. (2013). Child sexual abuse in China: A meta-analysis of 26 studies. Child Abuse \& Neglect, 37(9), 613-622.

Johnson, T.C. (1999). Understanding Your Child's Sexual Behavior. Oakland, CA: New Harbinger Publications.

Johnson, T.C. (2005). Young Children's Problematic Sexual Behaviors, Unsubstantiated Allegations of Child Sexual Abuse, and Family Boundaries in Child Custody Disputes. Journal of Child Custody, 2(4), 111-126.

Johnson, T.C. \& Hooper, R. (2003). Boundaries and family practices: Implications for assessing child abuse. Journal of Child Sexual Abuse, 12(3/4), 103-126.

Johnson, T.C., Huang, B.E. \& Simpson, P. M. (2009). Sibling Family Practices: Guidelines for Healthy Boundaries. Journal of Child Sexual Abuse, 18(3), 339-354.

Lewis, R.J., \& Janda, L.H. (1988). The relationship between adult sexual adjustment and childhood experiences regarding exposure to nudity, sleeping in the parental bed, and parental attitudes toward sexuality. Archives of Sexual Behavior, 17, 349-362.

Magalhães, T., Taveira, F., Jardim, P., Santos, L., Matos, E., \& Santos, A. (2009). Sexual abuse of children. A comparative study of intra and extra-familial cases. Journal of Forensic and Legal Medicine, 16, 455-459. 
Miller, J. (2012). Psychosocial Capacity Building in Response to Disaster. NY: Columbia University Press.

Miller-Perrin, C.L. \& Perrin, R.D. (2006). Child Maltreatment: An Introduction (2nd. Ed.). CA: Sage Publications, Inc.

National Sexual Violence Resource Center (2012). Understanding child sexual abuse: Definitions and rates. Enola, PA: Author.

National Society for the Prevention of Child Abuse (2013). Child Sexual Abuse: An NSPCC Research Briefing. Accessed at https://www.nspcc.org.uk/globalassets/documents/informationservice/research-briefing-child-sexual-abuse.pdf

Okami, P. (1995). Childhood exposure to parental nudity, parent-child co-sleeping, and "primal scenes": A review of clinical opinion and empirical evidence. Journal of Sex Research, 32(1), 51-63.

Okami, P.R., Olmstead, R., Abramson, P., \& Pendleton, L. (1998). Early childhood exposure to parental nudity and scenes of parental sexuality ("Primal Scenes"): An 18-year longitudinal study of outcome. Archives of Sexual Behavior, 27(4), 361-384.

Qiao, D.P. \& Xie, Q.W. (2017) Public perceptions of physical child abuse in mainland China. Child \& Family Social Work. 22(1), 213-225.

Reynolds, L. L. \& Birkimer, J. C. (2002). Perceptions of child sexual abuse: Victim and perpetrator characteristics, treatment efficacy, and lay vs. legal opinions of abuse. Journal of Child Sexual Abuse, 11(1), 53-74.

Rogers, P., Davies, M., Anderson, I. \& Potton, A. (2011). Can norm theory explain the effects of victim age and level of physical maturity on perceptions of child sexual abuse? Journal of Interpersonal Violence, 26(10) 1911-1933.

Rosenfeld, A. A., Siegel, B., \& Bailey, R. (1987). Familial bathing patterns: Implications for cases of alleged molestation and for pediatric practice. Pediatrics, 79, 224-229.

Rothbaum, F., Morelli, G., Pott, M., \& Liu, Y. (2000). Immigrant-Chinese and Euro-American parents' physical closeness with young children: themes of family relatedness. Journal of Family Psychology, 14(3): 334-348.

Thevenin, T. (1987). The Family Bed. Wayne, NJ: Avery Publishing Group, Inc.

Tahhan, D. A. (2008). Touching at depth: Intimate spaces in the Japanese family. Dissertation for the Doctor of Philosophy in University of New South Wales.

U.S. Department of Health and Human Services, Administration on Children, Youth and Families. (2005). Child Maltreatment 2003. Washington, DC: Government Print Office.

Waldfogel, J., (2001). The Future of Child Protection: How to Break the Cycle of Abuse and neglect. MA: Harvard University Press.

Xie, Q.W., Qiao, D.P. \& Wang, X.L. (2016). Parent-involved Prevention of Child Sexual Abuse: A Qualitative Exploration of Parents' Perceptions and Practices in Beijing. The Journal of Child and Family Study, 25(3), 999-1010.

Xie, Q.W., Sun, X., Chen, M., Qiao, D.P., \& Chan, K.L. (2017). What prevents Chinese parents from reporting possible cases of child sexual abuse to authorities? A holistic-interactionistic approach. Child Abuse \& Neglect, 64, 19-31.

Yan, N. (2010). Values of "Post-90" College Students (MPhil Thesis). Nanjing University of Science \& Technology. (In Chinese). 